\title{
Clinical and nutritional status in the late postoperative of pancreaticoduodenectomy. Influence of pylorus preservation procedure ${ }^{1}$
}

\author{
Estado clínico e nutricional no pós-operatório tardio de pancreaticoduodenectomia. Influência \\ da preservação do piloro
}

\author{
Cinara Knychala Muniz ${ }^{\mathrm{I}}$, Camila Bitu Moreno Braga ${ }^{\mathrm{II}}$, Rafael Kemp ${ }^{\mathrm{III}}$, José Sebastião dos Santos ${ }^{\mathrm{IV}}$, Selma Freire de Carvalho \\ da Cunhav
}

IFellow PhD degree, Postgraduate Program on Internal Medicine, RD, Faculty of Medicine, Ribeirao Preto-SP, Brazil. Study concept and design; acquisition, analysis, and interpretation of data, manuscript writing.

IRD, M.Sc,, Fellow PhD degree, Postgraduate Program on Internal Medicine, RD, Faculty of Medicine, Ribeirao Preto-SP, Brazil. Technical procedures, interpretation of data, critical revision of the manuscript.

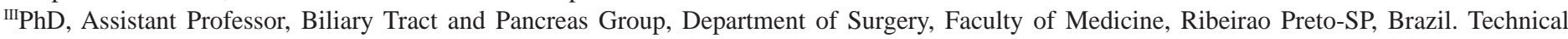
procedures, critical revision of the manuscript.

${ }^{\mathrm{IV}} \mathrm{PhD}$, Associate Professor, Biliary Tract and Pancreas Group, Department of Surgery, Faculty of Medicine, Ribeirao Preto-SP, Brazil. Analysis and interpretation of data, critical revision of the manuscript.

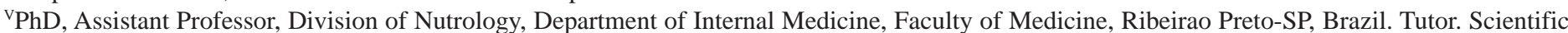
and intellectual content of the study, statistic analysis, interpretation of data, critical revision, manuscript writing.

\begin{abstract}
PURPOSE: To evaluate the nutritional status of patients in the late postoperative period of pancreaticoduodenectomy (PD) and compare the long-term outcome according to pylorus-preserving (PPPD) or the standard technique (SPD) in which the pylorus is resected.

METHODS: This prospective study was conducted twelve months prior or more in patients who had underwent PD (PD Group, $\mathrm{n}=15$ ) and health volunteers (Control Group, $\mathrm{n}=15$ ). At a post hoc analysis, the PD Group was divided in PPPD Subgroup ( $\mathrm{n}=9$ ) and SPD Subgroup $(n=6)$, according to the PD techniques. Gastrointestinal complaints and nutritional status were evaluated, apart from a biochemical assessment; Student t-test or Mann-Whitney test were used.

RESULTS: The patients recovered their body weight and the gastrointestinal complaints were uncommon. The PD Group showed higher energy and protein intake even though BMI was lower than in Control Group. There were no differences in laboratorial data, except for higher glycemia, serum alkaline phosfatase and C-reactive protein in PD Group. There was no difference in the various parameters evaluated when the Subgroups (PPPD and SPD) were compared.
\end{abstract}

CONCLUSION: For long-term pancreaticoduodenectomy, the gastrointestinal symptoms are minimal and the patients had the clinical and nutritional status preserved, regardless of pylorus preservation.

Key words: Pancreaticoduodenectomy. Nutritional Status. Anthropometry. Blood Proteins.

\section{RESUMO}

OBJETIVO: Avaliar o estado nutricional de pacientes em pós-operatório tardio de pancreaticoduodenectomia (PD) e comparar a evolução de acordo com a preservação de piloro (PPPD) ou pela técnica padrão com ressecção do piloro (SPD).

MÉTODOS: O estudo prospectivo foi conduzido com pacientes submetidos à PD após período mínimo de 12 meses (Grupo PD, n=15) e voluntários saudáveis (Grupo Controle, $n=15$ ). Numa análise posterior, o Grupo PD foi dividido em Subgrupo PPPD ( $\mathrm{n}=9$ ) e Subgrupo SPD $(n=6)$, de acordo com a técnica de PD. Foram avaliadas as queixas digestivas, o estado nutricional e dados bioquímicos; a análise estatística foi realizada por meio do teste t-Student ou Mann-Whitney.

RESULTADOS: Os pacientes recuperaram o estado nutricional e as queixas gastrointestinais foram incomuns. A ingestão protéica e energética foi maior no Grupo PD, apesar do menor IMC. Não houve diferenças em relação aos exames laboratoriais, exceto pelos maiores níveis de glicemia, fosfatase alcalina sérica e proteína C-reativa no Grupo PD. Quando os Subgrupos PPPD e SPD foram comparados, não houve diferenças nos diversos parâmetros analisados.

CONCLUSÃO: No pós-operatório tardio de pancreaticoduodenectomia, os sintomas gastrointestinais são mínimos e o estado clínico e nutricional é adequado, independente da preservação do piloro.

Descritores: Pancreaticoduodenectomia. Estado Nutricional. Antropometria. Proteínas Sanguíneas. 


\section{Introduction}

Pancreaticoduodenectomy (PD) has been performed in the treatment of a considerable number of malignant diseases such as pancreas, duodenum, ampullary and distal bile duct cancer and some benign diseases ${ }^{1-2}$. In recent decades, several studies have been conducted to evaluate clinical and nutritional longterm effects after $\mathrm{PD}^{3-8}$. However, most studies have not made a complete nutritional assessment and they do not describe digestive complaints or details of food intake patterns. Moreover, the PD techniques haven't been standardized or described in detail, which may compromise the critical analysis of the results.

Among the surgical factors that may influence the clinical outcomes, the International Study Group of Pancreatic Surgery reported the pancreatoenteric anastomosis such as the use of pancreatojejunostomy and pancreatogastrostomy, duct-tomucosa anastomosis, invagination (dunking) of the remnant into the jejunum or stomach, and the use of a stent (internal or external) across the anastomosis ${ }^{9}$. In the standard pancreaticoduodenectomy (SPD, or classical Whipple's procedure), the head of the pancreas, duodenum, common bile duct, gallbladder, and distal stomach, including the pylorus are resected and the gastrointestinal tract is restored by gastrojejunostomy. The pancreaticoduodenectomy pylorus-preserving PD (PPPD) is similar to SPD, except that the antrum and pylorus are left intact, and the gastrointestinal tract is restored by duodenojejunostomy ${ }^{10}$.

Perform studies have been recommended, which avoid potentially biasing variables and which clarify the impact of surgical techniques on the clinical and nutritional status years after surgery ${ }^{9}$. These data would allow the establishment of guidelines in order to improve the life quality of pancreas, ampullary and periampullary cancer survivors. The purpose of this study was to evaluate the nutritional status of patients in the late postoperative period of pancreaticoduodenectomy, apart from comparing the outcome according with pylorus-preserving pancreaticoduodenectomy (PPPD) and standard pancreaticoduodenectomy (SPD) techniques.

\section{Methods}

This study was conducted in a public university hospital after approval by the institutional Ethics Committee and all subjects signed an informed consent. A list containing 71 names of patients who underwent PD between 2000 and 2010 was obtained. Twentyfive patients were deceased and 17 individuals had inconsistent registration data and/or impossibility of contact by telephone. Eight patients were excluded because they were less than one year from surgery and they received postoperative adjuvant chemotherapy. Four individuals were undergoing chemotherapy due to residual or recurrent neoplastic disease and two subjects refused to participate. No patient showed increased serum levels of CA199 or evidence of thoracic and abdominal mass at computerized tomography. Upper gastrointestinal endoscopy was done by the same endoscopist and no patient presented obstructions in the pancreaticojejunal and hepaticojejunal anastomoses.

The final casuistic included patients who underwent PD (PD Group, $\mathrm{n}=15$ ) twelve months prior to evaluation or more, 12 men and 3 women, $60.4 \pm 13.2$ years. At a post hoc analysis, the PD Group was divided in PPPD Subgroup $(n=9)$ and SPD Subgroup ( $n=6$ ), according to the PD techniques. The individual description of the surgical procedure, the histopathological diagnosis and the TNM classification were obtained by medical record review (Table 1). The study also included health volunteers (Control Group, n=15), 11 men and 4 women, $58.1 \pm 12.6$ years, paired by socioeconomic levels. 
TABLE 1 - Demographic characteristics of patients who underwent PD surgery, time elapsed after surgery, histopathological diagnosis and TNM classification.

\begin{tabular}{|c|c|c|c|c|c|c|}
\hline Case & $\begin{array}{c}\text { Type of PD } \\
\text { surgery }\end{array}$ & Gender & $\begin{array}{c}\text { Age } \\
\text { (years) }\end{array}$ & $\begin{array}{c}\text { Time elapsed after } \\
\text { surgery (months) }\end{array}$ & Histopathological diagnosis & TNM classification \\
\hline 1 & SPD & Male & 61 & 120 & Carcinoma of papilla of Vater & pT2N0M0 \\
\hline 2 & SPD & Female & 63 & 120 & Carcinoma of papilla of Vater & pT2N0M0 \\
\hline 3 & SPD & Male & 79 & 119 & Carcinoma of papilla of Vater & pT3N0Mx \\
\hline 4 & SPD & Male & 79 & 108 & Carcinoma of papilla of Vater & pT1N1M0 \\
\hline 5 & SPD & Male & 57 & 65 & Carcinoma of papilla of Vater & pT1N1Mx \\
\hline 6 & SPD & Male & 63 & 12 & Carcinoma of papilla of Vater & pT3N0M1 \\
\hline 7 & PPPD & Male & 60 & 52 & Neuroendocrine tumor & Not applicable \\
\hline 8 & PPPD & Male & 61 & 46 & Carcinoma of papilla of Vater & pT3N1M0 \\
\hline 9 & PPPD & Male & 53 & 45 & Distal bile duct carcinoma & pT3N0M0 \\
\hline 10 & PPPD & Male & 67 & 31 & Carcinoma of papilla of Vater & pT3N1Mx \\
\hline 11 & PPPD & Male & 69 & 30 & Pancreatic head carcinoma & pT3N0Mx \\
\hline 12 & PPPD & Female & 64 & 29 & Carcinoma of papilla of Vater & pT2N1M0 \\
\hline 13 & PPPD & Male & 58 & 20 & Carcinoma of papilla of Vater & pT2N0M0 \\
\hline 14 & PPPD & Female & 24 & 13 & Frantz' tumor & Not applicable \\
\hline 15 & PPPD & Male & 50 & 12 & Desmoid tumor & Not applicable \\
\hline
\end{tabular}

\section{Surgical procedures}

All PD patients were assessed at least 12 months after surgery. This postoperative period was chosen to exclude the possibility that the assessment of clinical and nutritional parameters could have been influenced by inflammatory stress due to surgery or concurrent illness. All patients were operated on by a single team, using the standard techniques. Except for the presence (PPPD Subgroup) or absence of antrum and pylorus (SPD Subgroup), the same procedures were performed in all patients, which included: (a) single-loop pancreatic and biliary reconstruction; (b) pancreatojejunostomy; (c) duct-to-mucosa anastomosis; (d) internal pancreatic duct silicone stent (6 to $10 \mathrm{Fr}$, around $10 \mathrm{~cm}$ ) and (e) interrupted suturing with polyprolpylene 5-0 suture.

\section{Gastrointestinal complaints and nutritional status}

All patients were interviewed regarding their gastrointestinal symptoms, like anorexia, abdominal pain, early satiety, diarrhea, steatorrhea and dumping. All volunteers were assessed by a registered dietitian. The analysis of the composition 
of the habitual diet was based upon the Semi-Quantitative Food Frequency Questionnaire, using a book containing pictures of food portions in different sizes as well as of cooking utensils. The nutrient intake was computed over the preceding six-month period, by means of specific software (NutWin Profissional ${ }^{\circledR} 1.5$ - Software, UNIFESP, Sao Paulo, Brazil). The energy and protein intake were expressed by body weight and vitamins and minerals were compared with the specific recommendations.

Anthropometric measurements were done using standard techniques and included weight, height, body mass index (BMI, weight/height ${ }^{2}$ ). The Subjective Global Assessment (SGA) ranked patients into three groups: well-nourished, moderately or suspected of being malnourished, and severely malnourished ${ }^{11}$.

\section{Laboratorial assessment}

Visceral protein mass was determined by measuring the total protein, albumin and transferrin serum concentrations. Immune competence was indirectly assessed by measuring the total lymphocyte counts. Other laboratory tests included hemoglobin, mean corpuscular volume, serum mineral and electrolytes, fasting glucose, liver enzymes, uric acid and plasmatic lipids. C-reactive protein was measured to act as a screen for inflammatory stress.

\section{Statistical analysis}

Data analyses were performed with the Statistica ${ }^{\circledR}$ software (version 7.0, StatSoft Inc, Tulsa, Oklahoma, USA). Variables with normal distribution were analyzed by Student t-test and reported as mean \pm SDs. Those with non-normal distribution were analyzed by Mann-Whitney test and reported as median values and range. Statistical significance was set at $\mathrm{p}<0.05$.

\section{Results}

\section{Gastrointestinal complaints and nutritional status}

No PD patient complained at anorexia or early satiety. A slight reduction in the amount of food ingested in the last 2 weeks was reported by two patients, and it was attributed to injuries in the oral cavity. Mild abdominal pain, eructation and postprandial epigastric fullness were cited by three patients, independent of the preservation of the antrum and pylorus. In PPPD Subgroup, one patient used oral anti-diabetic drugs and pancreatic enzyme supplements regularly due to endocrine and exocrine pancreatic insufficiency. Only one patient used insulin regularly, but he had diabetes mellitus diagnosed before the PD. Dumping was diagnosed in one patient in PPPD Subgroup, who also exhibited exocrine pancreatic insufficiency and used enzyme therapy.
Compared to Control Group, the PD Group had a higher energy (41.7 \pm 9.4 vs. $29.3 \pm 9.7 \mathrm{kcal} / \mathrm{kg}, \mathrm{p}=0.001)$ and protein intake $(1.6 \pm 0.5$ vs. $1.1 \pm 0.3 \mathrm{~g} / \mathrm{kg}, \mathrm{p}=0.01)$. The vitamins and minerals were similar between the groups and in accordance with the recommendations. There were not significant differences in the energy ( $39.1 \pm 8.5 \mathrm{vs.} 45.7 \pm 10.1 \mathrm{kcal} / \mathrm{kg}, \mathrm{p}=0.19$ ) and protein $(1.6 \pm 0.5$ vs. $1.5 \pm 0.6 \mathrm{~g} / \mathrm{kg}, \mathrm{p}=0.57)$ between PPPD and SPD Subgroups when the dietary intake data were compared.

Although PD patients had presented a weight loss of 20.1 (7.1-35.4) kg following surgery, at the time of evaluation they had recovered $90.8 \pm 10.7 \%$ of their lost weight. In the last 6 months, only two patients had lost body weight (<10\%) and nobody complained at diminished functional capacity. At evaluation, the BMI was lower in PD Group than in Control Group (24.5 \pm 3.9 vs. $\left.27.4 \pm 3.5 \mathrm{~kg} / \mathrm{m}^{2}, \mathrm{p}=0.004\right)$. However, the BMI $(25.4 \pm 4.4 \mathrm{vs}$. $23.2 \pm 2.9 \mathrm{~kg} / \mathrm{m}^{2}, \mathrm{p}=0.32$ ) was similar between PPPD and SPD Subgroups. Based on SGA, only one patient (PPPD Subgroup) was moderately or suspected of being malnourished, the others were considered as well nourished.

\section{Laboratorial assessment}

Laboratory data regarding clinical and nutritional status of PD and Control Groups (Table 2) show no differences, except for higher values of glycemia, alkaline phosphatase and C-reactive protein in the PD Group. Fasting glucose higher than $110 \mathrm{mg} / \mathrm{dL}$ was documented in 4 patients of PPPD Subgroup and 1 patient of SPD Subgroup. 
TABLE 2 - Clinical and nutritional laboratory data in the PD and Control Groups.

\begin{tabular}{|c|c|c|c|c|}
\hline & $\begin{array}{l}\text { PD Group } \\
\quad(n=15)\end{array}$ & $\begin{array}{l}\text { Control Group } \\
\qquad(\mathrm{n}=15)\end{array}$ & $p$ value & Normal range \\
\hline Total protein (g/dL) & $7.1 \pm 0.6$ & $6.7 \pm 0.2$ & 0.03 & $6.0-8.5$ \\
\hline Albumin (g/dL) & $4.2 \pm 0.9$ & $4.3 \pm 0.2$ & 0.29 & $3.5-4.8$ \\
\hline Transferrin (mg/dL) & $220 \pm 51$ & $204 \pm 29$ & 0.29 & $<170$ \\
\hline Hemoglobin (g/dL) & $14.2 \pm 1.5$ & $14.8 \pm 1.5$ & 0.29 & $13.5-17.5$ \\
\hline Mean corpuscular volume (fL) & $92 \pm 4$ & $91 \pm 5$ & 0.78 & 81-95 \\
\hline Total lymphocytes (cells/mm³) & $1873 \pm 771$ & $1886 \pm 497$ & 0.95 & $900-2900$ \\
\hline $\operatorname{Iron}(\mathrm{mg} / \mathrm{dL})$ & $94 \pm 27$ & $104 \pm 33$ & 0.41 & $40-160$ \\
\hline Copper ( $\mu \mathrm{g} / \mathrm{dL})$ & $105 \pm 30$ & $94 \pm 17$ & 0.25 & $70-140$ \\
\hline Sodium $(\mathrm{Mmol} / \mathrm{L})$ & $139 \pm 2$ & $140 \pm 3$ & 0.22 & $135-145$ \\
\hline Potassium (Mmol/L) & $4.4 \pm 0.4$ & $4.3 \pm 0.4$ & 0.56 & $3.5-5.0$ \\
\hline Glycemia (mg/dL) & $107 \pm 29$ & $87 \pm 15$ & 0.03 & $70-100$ \\
\hline Creatinine (mg/dL) & $1.0 \pm 0.2$ & $1.0 \pm 0.2$ & 0.97 & $0.7-1.5$ \\
\hline Total bilirrubin (mg/dL) & $0.7 \pm 0.4$ & $0.7 \pm 0.2$ & 0.93 & $0.2-1.2$ \\
\hline Alkaline phosfatase (U/L) & $295 \pm 150$ & $172 \pm 34$ & 0.004 & $65-300$ \\
\hline Alanine aminotransferase (U/L) & $18(10-298)$ & $23(12-88)$ & 0.36 & $<38$ \\
\hline Aspartate aminotransferase (U/L) & $27(14-173)$ & $24(19-44)$ & 0.62 & $<41$ \\
\hline$\square$-Glutamyl transferase (mg/dL) & $33(21-211)$ & $35(19-216)$ & 0.90 & $11-50$ \\
\hline Uric acid (mg/dL) & $4.7 \pm 1.2$ & $5.5 \pm 1.8$ & 0.17 & $2.5-6.0$ \\
\hline Total cholesterol (mg/dL) & $170 \pm 42$ & $197 \pm 34$ & 0.07 & $<200$ \\
\hline LDL-cholesterol (mg/dL) & $107 \pm 30$ & $120 \pm 28$ & 0.26 & $<130$ \\
\hline HDL-cholesterol (mg/dL) & $41 \pm 9$ & $48 \pm 11$ & 0.06 & $>35$ \\
\hline Triglycerides (mg/dL) & $110 \pm 48$ & $147 \pm 93$ & 0.19 & $<150$ \\
\hline C-reactive protein (mg/dL) & $0.26(0.06-2.61)$ & $0.15(0.01-0.72)$ & 0.01 & $<0.5$ \\
\hline
\end{tabular}

In the PD Group, there was no statistical difference when the laboratorial parameters were compared according to PPPD and SPD techniques (Table 3). The visceral proteins were within the normal limits for all patients, except in one case following SPD, which presented total protein and albumin at normality's lower limit. 
TABLE 3 - Clinical and nutritional laboratory data in the PPPD and SPD SubGroups.

\begin{tabular}{cccc}
\hline & $\begin{array}{c}\text { PPPD Subgroup } \\
(\mathrm{n}=9)\end{array}$ & $\begin{array}{c}\text { SPD Subgroup } \\
(\mathrm{n}=6)\end{array}$ & p value \\
\hline Total protein (g/dL) & $7.2 \pm 0.6$ & $6.9 \pm 0.7$ & 0.45 \\
Albumin (g/dL) & $4.3 \pm 0.4$ & $4.0 \pm 0.3$ & 0.22 \\
Transferrin (mg/dL) & $224 \pm 57$ & $215 \pm 47$ & 0.76 \\
Hemoglobin (g/dL) & $14.6 \pm 1.8$ & $13.6 \pm 0.8$ & 0.21 \\
Mean corpuscular volume (fL) & $91 \pm 5$ & $93 \pm 4$ & 0.40 \\
Total lymphocytes (cells/mm $)$ & $2056 \pm 572$ & $1600 \pm 547$ & 0.28 \\
Iron (mg/dL) & $102 \pm 32$ & $83 \pm 15$ & 0.21 \\
Copper ( $\mu \mathrm{gg} / \mathrm{dL})$ & $108 \pm 33$ & $100 \pm 25$ & 0.65 \\
Sodium (Mmol/L) & $139 \pm 2$ & $138 \pm 2$ & 0.65 \\
Potassium (Mmol/L) & $4.3 \pm 0.4$ & $4.5 \pm 0.5$ & 0.44 \\
Glycemia (mg/dL) & $114 \pm 35$ & $96 \pm 12$ & 0.26 \\
Creatinine (mg/dL) & $0.9 \pm 0.1$ & $1.1 \pm 0.3$ & 0.40 \\
Total bilirrubin (mg/dL) & $0.8 \pm 0.5$ & $0.6 \pm 0.3$ & 0.27 \\
Alkaline phosfatase (U/L) & $334 \pm 172$ & $236 \pm 94$ & 0.23 \\
Alanine aminotransferase (U/L) & $20(14-298)$ & $17(10-40)$ & 0.89 \\
Aspartate aminotransferase (U/L) & $27(14-173)$ & $25(19-40)$ & 1.00 \\
$\square$-Glutamyl transferase (mg/dL) & $37(24-184)$ & $30(21-211)$ & 0.22 \\
Uric acid (mg/dL) & $4.6 \pm 1.4$ & $4.9 \pm 0.9$ & 0.60 \\
Total cholesterol (mg/dL) & $170 \pm 31$ & $170 \pm 61$ & 0.99 \\
LDL-cholesterol (mg/dL) & $108 \pm 23$ & $106 \pm 44$ & 0.88 \\
HDL-cholesterol (mg/dL) & $39 \pm 5$ & $44 \pm 13$ & 0.29 \\
Triglycerides (mg/dL) & $114 \pm 37$ & $102 \pm 68$ & 0.65 \\
C-reactive protein (mg/dL) & $0.23(0.06-2.61)$ & 0.68 \\
\hline
\end{tabular}

\section{Discussion}

This study shows that digestive complaints were mild and body weight was within normal limits in patients undergoing PD. The patients had higher blood glucose, alkaline phosphatase and C-reactive protein when compared to Control Group. There were no differences in the various parameters evaluated when the patients submitted to PD were analyzed according to whether or not the preservation of the antrum and pylorus was performed.

In the late postoperative period, the appetite and dietary intake are limited by gastrointestinal symptoms like nausea, flatulence, epigastric fullness, vomiting, and diarrhea ${ }^{8}$. In this study, the gastrointestinal symptoms were scarce and seemed not to have interfered with the usual food intake. Only two patients (13.3\%) showed steatorrhea and needed pancreatic enzymes, while this condition varied from 18 to $73 \%$ in several studies ${ }^{4,5,8,12,13}$. In our casuistic, the lower number of patients with pancreatic exocrine insufficiency can be attributed to the efficiency of duct-to-mucosa pancreatojejunal anastomosis. Some researches showed that the pancreatic exocrine insufficiency was less frequent when pancreas anastomosis was performed in the jejunum (pancreatojejunostomy) than in the stomach (pancreatogastrostomy) ${ }^{14,15}$.

In our series, the energy and protein intake were higher in the PD Group than in the Control Group. Some studies have reported that the $\mathrm{PD}$ patients had adequate energy intake ${ }^{16}$ and similar to patients who underwent subtotal gastrectomy ${ }^{12}$, cholecystectomy $^{13}$ or healthy controls ${ }^{17}$. Our results can be attributed to good adherence to dietary guidelines but it is possible 
that the food intake was over-reported due to limitations inherent to food questionnaires methodologies ${ }^{18}$.

In the present study, PD patients had a recovery of around $90 \%$ of the previous body weight and they presented weight within the normal range. Early studies showed that $50^{19}$ to $25 \%{ }^{20}$ of patients undergoing $\mathrm{PD}$ have not recovered the body weight postoperatively. Our results are similar to studies conducted during the 90's which showed a recovery of 85 to $95 \%$ of the lost weight after at least 4 months of $\mathrm{PD}^{6,12}$ and adequacy of anthropometric data ${ }^{4,6,17}$. The weight restoring is determined by the food intake pattern, pancreatic insufficiency extent and the raise in energy expenditure. The only patient who was considered as malnourished by the SGA or anthropometric data had exocrine pancreatic insufficiency. The difference in the BMI values between the PD and Control Groups can be attributed to the fact that some subjects in the Control Group were overweight. However, considering the prevalence of hyperglycemia in our patients, it is possible that endocrine pancreatic failure justifies the lower body weight in PD Group.

Similarly to our results, some authors did not point any differences between the SPD and PPPD patients' weight ${ }^{4,5}$. However, the pylorus preservation seems to have advantages in the functional and nutritional status ${ }^{3,8}$. A longitudinal follow-up showed that differences in postoperative weight gain are correlated rather with resection margins and tumor recurrence than with the type of resection ${ }^{5}$.

Our patients showed no changes in protein metabolism markers and serum minerals. A low level of hemoglobin was not a common problem, although mild or severe anemia was documented in $28 \%$ of the patients who underwent $\mathrm{PD}^{4}$. Similar to our results, some studies showed normal transferrin levels in all patients ${ }^{4,12,21}$ and they observed no differences in the albumin levels between SPD and PPPD patients ${ }^{4,5,21}$. On the other hand, in a large group of cases which were evaluated at least 6 months postoperatively, higher serum albumin was demonstrated in patients undergoing PPPD as compared to $\mathrm{SPD}^{3}$.

In the present study both AST and ALT were at normal levels and no subject used hepatotoxic drugs. The increase in alkaline phosphatase suggests subclinical hepatobiliary involvement, even though cholangitis was not observed and endoscopy showed the anastomoses were wide and unobstructed. Contact between enteric content and the bile duct is a common occurrence after biliodigestive anastomosis and endoscopic biliary drainage $^{22}$. After biliodigestive anastomosis, transitory episodes of cholestasis and cholangitis have been documented in experimental models $^{23,24}$ and in humans ${ }^{25}$. It is possible that enteric contents stagnated in the excluded loop and in the biliary duct anastomosis could explain the increased alkaline phosphatase. The increased levels of C-reactive protein in PD Group may be part of liver dysfunction, as occur in other clinical situations ${ }^{26}$.

Among the strengths of this study we may point out the standardization of surgical techniques, including pancreaticojejunal anastomosis ${ }^{9}$, the strict inclusion criteria, and the simultaneous use of distinct techniques to assess the nutritional status. The limitation of this study was the small sample size, justified by the low survival rate of patients who underwent PD. In patients with unsatisfactory postoperative clinical and nutritional status, an exclusion of recurrent tumor activity and assessment of pancreatic exocrine function are mandatory. In addition, pancreatic endocrine function should be continuously monitored, especially when body weight is not adequate. Finally, small increases in liver enzymes should be measured and continuously monitored.

\section{Conclusion}

For long-term pancreaticoduodenectomy, the gastrointestinal symptoms are minimal and the patients had the clinical and nutritional status preserved, regardless of pylorus preservation.

\section{References}

1. Cameron JL, Riall TS, Coleman J, Belcher KA. One thousand consecutive pancreaticoduodenectomies. Ann Surg. 2006;244(1):105.

2. Pedrazzoli S, Canton SA, Sperti C. Duodenum-preserving versus pylorus-preserving pancreatic head resection for benign and premalignant lesions. J Hepatobiliary Pancreat Sci. 2011;18(1):94102.

3. Zerbi A, Balzano G, Patuzzo R, Calori G, Braga M, Di Carlo V. Comparison between pylorus-preserving and Whipple pancreatoduodenectomy. Br J Surg. 1995;82(7):975-9.

4. Melvin WS, Buekers KS, Muscarella P, Johnson JA, Schirmer WJ, Ellison EC. Outcome analysis of long-term survivors following pancreaticoduodenectomy. J Gastrointest Surg. 1998;2(1):72-8.

5. van Berge Henegouwen MI, Moojen TM, van Gulik TM, Rauws EAJ, Obertop H, Gouma DJ. Postoperative weight gain after standard Whipple's procedure versus pylorus-preserving pancreatoduodenectomy: the influence of tumour status. Br J Surg. 1998;85(7):922-6

6. Maskell C, Daniels P, Johnson CD. Dietary intake after pancreatectomy. Br J Surg. 1999;86(3):323-6.

7. Ohtsuka T, Yamaguchi K, Chijiiwa K, Tanaka M. Effect of gastrointestinal reconstruction on quality of life and nutritional status after pylorus-preserving pancreatoduodenectomy. Dig Dis Sci. 2002;47(6):1241-7.

8. Niedergethmann M, Shang E, Farag Soliman M, Saar J, Berisha S, Willeke F, Post S. Early and enduring nutritional and functional results of pylorus preservation vs classic Whipple procedure for pancreatic cancer. Langenbecks Arch Surg. 2006;391(3):195-202. 
9. Shukla PJ, Barreto SG, Fingerhut A, Bassi C, Büchler MW, Dervenis C, Gouma D, Izbicki JR, Neoptolemos J, Padbury R, Sarr MG, Traverso W, Yeo CJ, Wente MN. Toward improving uniformity and standardization in the reporting of pancreatic anastomoses: a new classification system by the International Study Group of Pancreatic Surgery (ISGPS). Surgery. 2010;147(1):144-53.

10. Diener MK, Knaebel HP, Heukaufer C, Antes G, Büchler MW, Seiler CM. A systematic review and meta-analysis of pyloruspreserving versus classical pancreaticoduodenectomy for surgical treatment of periampullary and pancreatic carcinoma. Ann Surg. 2007;245(2):187-200.

11. Detsky AS, McLaughlin JR, Baker JP, Johnston N, Whittaker $\mathrm{S}$, Mendelson RA, Jeejeebhoy KN. What is subjective global assessment of nutritional status? JPEN J Parenter Enteral Nutr. 1987;11(1):8-13.

12. Ong HS, Ng EH, Heng G, Soo KC. Pancreaticoduodenectomy with pancreaticogastrostomy: Assessment of patients' nutritional status, quality of life and pancreatic exocrine function. Aust N Z J Surg. 2000;70(3):199-203.

13. McLeod RS. Quality of life, nutritional status and gastrointestinal hormone profile following the Whipple procedure. Ann Oncol. 1999;10(Suppl 4):281-4.

14. Jang JY, Kim SW, Park SJ, Park YH. Comparison of the functional outcome after pylorus-preserving pancreatoduodenectomy: pancreatogastrostomy and pancreatojejunostomy. World J Surg. 2002;26(3):366-71.

15. Rault A, SaCunha A, Klopfenstein D, Larroudé D, Epoy FN, Collet D, Masson B. Pancreaticojejunal anastomosis is preferable to pancreaticogastrostomy after pancreaticoduodenectomy for longterm outcomes of pancreatic exocrine function. J Am Coll Surg. 2005;201(2):239-44.

16. Armstrong T, Walters E, Varshney S, Johnson CD. Deficiencies of micronutrients, altered bowel function, and quality of life during late follow-up after pancreaticoduodenectomy for malignancy. Pancreatology. 2002;2(6):528-34.

17. Armstrong T, Strommer L, Ruiz-Jasbon F, Shek FW, Harris SF, Permert J, Johnson CD. Pancreaticoduodenectomy for periampullary neoplasia leads to specific micronutrient deficiencies. Pancreatology. 2007;7(1):37-44.

18. Cardoso MA, Tomita LY, Laguna EC. Assessing the validity of a food frequency questionnaire among low-income women in São Paulo, southeastern Brazil. Cad Saúde Pública. 2010;26(11):205967.

19. Fish JC, Smith LB, Williams RD. Digestive function after radical pancreaticoduodenectomy. Am J Surg. 1969;117(1):40-5.

20. Traverso WL, Longmire WP Jr. Preservation of the pylorus in pancreaticoduodenectomy: a follow-up evaluation. Ann Surg. 1980;192(3):306-10.

21. Royall D, Jeejeebhoy KN, O'Connor B, Taylor BR, Langer B, McLeod RS. Nutritional status and function in patients following Whipple procedure compared with controls. J Am Coll Nutr. 1996;15(1):73-8.

22. Santos JS, Junior WS, Modena JL, Brunaldi JE, Ceneviva R. Effect of preoperative endoscopic decompression on malignant biliary obstruction and postoperative infection. Hepatogastroenterology. 2005;52(61):45-7.

23. Klaus A, Weiss H, Kreczy A, Eigentler A, Neher C, Margreiter R, Pernthaler $\mathrm{H}$. A new biliodigestive anastomosis technique to prevent reflux and stasis. Am J Surg. 2001;182(1):52-7.

24. Dutra RA, Santos JS, Araújo WM, Simões MV, Paixão-Becker AN, Neder L. Evaluation of hepatobiliary excretion and enterobiliary reflux in rats with biliary obstruction submitted to bilioduodenal or biliojenunal anastomosis. Dig Dis Sci. 2008;53(4):1138-45.
25. Hashimoto N, Ohyanagi H. Hepatobiliary Scintigraphy after biliary reconstruction - A comparative study on Roux-Y and ESCD. Hepatogastroenterology. 2000;47(35):1210-2.

26. Takahashi A, Abe K, Yokokawa J, Iwadate H, Kobayashi H, Watanabe $\mathrm{H}$, Irisawa A, Ohira H. Clinical features of liver dysfunction in collagen diseases. Hepatol Res. 2010;40(11):1092-7.

\section{Correspondence:}

Selma Freire de Carvalho da Cunha

Departamento de Clinica Médica

Faculdade de Medicina de Ribeirão Preto, Universidade de São

Paulo

Avenida Bandeirantes, 3900

14048-900 Ribeirão Preto - SP Brasil

Tel.: (55 16)3602-3369

Fax: (55 16)3633-6695

sfreire@fmrp.usp.br

Received: September 20, 2011

Review: November 18, 2011

Accepted: December 21, 2011

Conflict of interest: none

Financial source: none

${ }^{1}$ Research performed at the Nutrology Division, Department of Internal Medicine and Biliary Tract and Pancreas Group, Department of Surgery, Faculty of Medicine (FMRP), Sao Paulo University (USP), Ribeirao Preto-SP, Brazil. Part of the PhD thesis of the first author. Tutor: Selma Freire C. Cunha. 